Research Article

\title{
Anti-inflammatory activity of theophylline on carrageenan-induced paw edema in male wistar rats
}

\author{
K Srinivasa $^{1}$, BVS Chandrasekhar ${ }^{2} *$, Srinivasa $^{3}$
}

\author{
${ }^{1}$ Associate Professor, ${ }^{2}$ Tutor, Department of \\ Pharmacology, KMCT Medical College, \\ Kozhikode-673602, Kerala, India \\ ${ }^{3}$ Associate Professor, Department of Physiology, \\ KMCT Medical College, Kozhikode-673602, \\ Kerala, India
}

Received: 18 February 2013

Accepted: 2 April 2013

\author{
*Correspondence to: \\ BVS Chandrasekhar, \\ Email: sekharpharma9@gmail.com
}

\begin{abstract}
(C) 2013 Srinivasa $\mathrm{K}$ et al. This is an open-access article distributed under the terms of the Creative Commons Attribution License, which permits unrestricted use, distribution, and reproduction in any medium, provided the original work is properly cited.
\end{abstract}

\begin{abstract}
Background: Evaluate the anti-inflammatory property of theophylline on rat hind paw edema using carrageenan-induced acute inflammatory model.

Methods: Wistar male rats (150-200 gm) were divided into 7 groups- 3 standard groups, 3 test groups and 1 control group. Each group consists of six rats. A control group was treated with $0.2 \mathrm{ml}$ of normal saline, 3 standard groups were treated with different doses of Diclofenac (Standard drug): $5 \mathrm{mg} / \mathrm{kg}, 10$ $\mathrm{mg} / \mathrm{kg}, 15 \mathrm{mg} / \mathrm{kg}$ body weight, respectively and 3 test groups were treated with different doses of Theophylline (Test drug): 5 $\mathrm{mg} / \mathrm{kg}, 10 \mathrm{mg} / \mathrm{kg}$ and $15 \mathrm{mg} / \mathrm{kg}$, respectively. The antiinflammatory property was assessed by plethysmograph.

Results: Theophylline demonstrated a significant antiinflammatory property at different dose levels when compared to controls $(p>0.05)$. However this anti-inflammatory activity was less as compared to standard drug.

Conclusions: Theophylline exhibited a dose dependent antiinflammatory activity in a carrageenan model of inflammation.
\end{abstract}

Keywords: Theophylline, Carrageenan, Anti-inflammatory activity

\section{INTRODUCTION}

Inflammation is a local response of living mammalian tissues to injury. It is a body defense reaction in order to eliminate or limit the spread of injurious agent. ${ }^{1}$ There are various components to an inflammatory reaction that can contribute to the associated symptoms and tissue injury. Edema, leukocyte infiltration, and granuloma formation represent such components of inflammation. Though, it is a defense mechanism. The complex events and mediators involved in the inflammatory reaction can induce or aggravate many reactions. ${ }^{2,3}$ Theophylline is commonly considered to be a bronchodilator. It has been used in the treatment of asthma and chronic obstructive pulmonary disease (COPD) for over 60 years and remains one of the most widely prescribed drugs for the treatment of airway diseases worldwide as it is inexpensive. ${ }^{4}$ There is considerable evidence to support an anti-inflammatory role for theophylline in asthma., ${ }^{5,6}$ It has been demonstrated that this drug is able to suppress, both in vitro and in vivo, a variety of inflammatory and immune cell functions. ${ }^{7}$ Apart from this, it has been shown that theophylline reduces the phagocytic and bactericidal capacities of polymorphonuclear leukocytes and macrophages, the release of reactive oxygen species by macrophages, the proliferative response of $\mathrm{T}$ lymphocytes to mitogens and the cytotoxic activity of natural killer as well as tumour necrosis factors release from activated human mononuclear cells. ${ }^{8}$

With these details taken into account, present study was planned to find out the possibility of anti-inflammatory activity of theophylline using carrageenan-induced acute inflammatory model.

\section{METHODS}

\author{
Animals \\ 42 male wistar rats (150-200 gm) were used for the \\ present study. They were fed with standard pellet diet and
}


water ad libitum. All animals were acclimatized for at least one week before the experimental session. All the experimental procedures were done following the guidelines of the Institutional Animals Ethics Committee.

\section{Evaluation of Anti-Inflammatory Activity}

For the anti-inflammatory activity against the acute inflammation, animals were divided into seven groups. Wistar rats weighing $150-200 \mathrm{gm}$ were selected. The animals were divided into seven groups containing 6 in each and labeled I-VII. Group I served as control $(0.2 \mathrm{ml}$ normal saline). Group II, III, and IV were treated with different doses of standard drug (Diclofenac sodium $5 \mathrm{mg} / \mathrm{kg}, 10 \mathrm{mg} / \mathrm{kg}, 15 \mathrm{mg} / \mathrm{kg}$; i.p.) whereas other groups V, VI and VII were treated (i.p.) with different doses of Theophylline $5 \mathrm{mg} / \mathrm{kg}, 10 \mathrm{mg} / \mathrm{kg}$ and $15 \mathrm{mg} / \mathrm{kg}$, respectively. Edema was produced by injecting freshly prepared $0.1 \mathrm{ml}$ of $1 \% \mathrm{w} / \mathrm{v}$ carrageenin suspension in sub plantar region of left hind paw of the animal. The volume of hind paw edema was measured by plethysmograph. Paw edema volume was measured at 0 hour and 3 hour after the injection of carrageenin. Drug pretreatment was given $30 \mathrm{~min}$ before the injection of carrageenin. The percent inhibition of edema was calculated by using following formula- $\frac{V c-V t}{V c} \times 100$ where $\mathrm{Vc}$ and $\mathrm{Vt}$ represents the average paw edema in controls and treated groups, respectively.

\section{Statistical analysis}

Results are expressed as Mean \pm S.E.M. The difference between experimental groups was compared by One-way Analysis of Variance (ANOVA). The results were considered statistically significant when $\mathrm{p}<0.05$.

\section{RESULTS}

The anti-inflammatory activity of the theophylline was evaluated by carrageenan-induced rat paw oedema method and the results are shown in Table 1 and Figure 1. The drug was tested at three different dose levels.

The paw edema showed signficant reduction in the groups treated with standard drug diclofenac and also with the theophylline treated groups when compared to controls ( $p>0.05$ ). The percentage inhibition was $10 \%$, $18.75 \%$ and $33.75 \%$ for theophyilline at doses of $5 \mathrm{mg} / \mathrm{kg}$, $10 \mathrm{mg} / \mathrm{kg}$ and $15 \mathrm{mg} / \mathrm{kg}$, respectively. However, these percentage inhibition were signficantly lower as compared to the reference drug diclofenac at all dose levels (Table 1 and Figure 1).

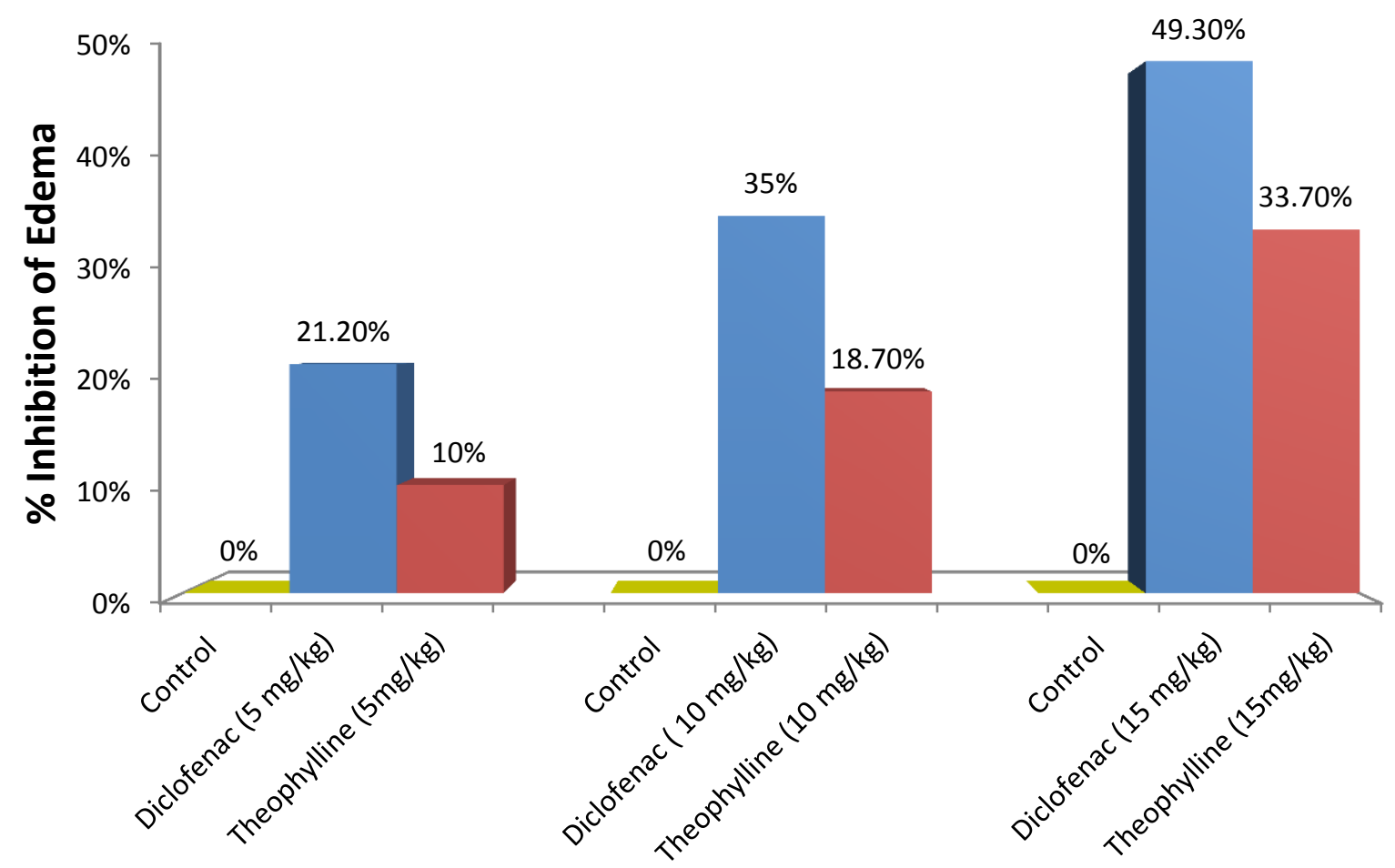

Figure 1: Percentage (\%) inhibition of rat hind paw edema (anti inflamatory activity). 
Table 1: Anti-inflammatory activity of theophylline.

\begin{tabular}{|lll|}
\hline Groups & $\begin{array}{l}\text { Paw edema } \\
\text { volume }(\mathrm{cm})\end{array}$ & $\begin{array}{l}\text { \% inhibition } \\
\text { of edema } \\
\text { compared to } \\
\text { control at } \\
\text { 3rd hour }\end{array}$ \\
\hline $\begin{array}{l}\text { Control } \\
\text { (Normal saline) }\end{array}$ & $0.8 \pm 0.036$ & \\
\hline $\begin{array}{l}\text { Diclofenac } \\
(5 \mathrm{mg} / \mathrm{kg})\end{array}$ & $0.62 \pm 0.033^{\mathrm{b}}$ & $21.2 \%$ \\
\hline $\begin{array}{l}\text { Theophylline } \\
(5 \mathrm{mg} / \mathrm{kg})\end{array}$ & $0.72 \pm 0.240^{\mathrm{a}, \mathrm{c}}$ & $10 \%$ \\
\hline $\begin{array}{l}\text { Diclofenac } \\
(10 \mathrm{mg} / \mathrm{kg})\end{array}$ & $0.52 \pm 0.030^{\mathrm{b}}$ & $35 \%$ \\
\hline $\begin{array}{l}\text { Theophylline } \\
(10 \mathrm{mg} / \mathrm{kg})\end{array}$ & $0.65 \pm 0.022^{\mathrm{a}, \mathrm{c}}$ & $18.7 \%$ \\
\hline $\begin{array}{l}\text { Diclofenac } \\
(15 \mathrm{mg} / \mathrm{kg})\end{array}$ & $0.42 \pm 0.030^{\mathrm{b}}$ & $49.3 \%$ \\
\hline $\begin{array}{l}\text { Theophylline } \\
(15 \mathrm{mg} / \mathrm{kg})\end{array}$ & $0.53 \pm 0.021^{\mathrm{a}, \mathrm{c}}$ & $33.7 \%$ \\
\hline
\end{tabular}

Values are mean \pm S.E.M.

a $p<0.05$, significantly different between theophylline and control groups.

b $\mathrm{p}<0.05$, significantly different between diclofenac and control groups.

c $p<0.05$, significantly different between theophylline and diclofenac groups.

\section{DISCUSSION}

Carrageenan-induced rat paw edema model is a suitable test for evaluating anti-inflammatory drugs, which has frequently been used to assess the antiedematous effect of the drug. Carrageenan is a strong chemical use for the release of inflammatory and proinflammatory mediators (prostaglandins, leukotrienes, histamine, bradykinin, TNF- $\alpha$, etc). ${ }^{10}$

The course of acute inflammation is biphasic. First phase starts with the release of histamine, serotonin, and kinins after the injection of phlogistic agent in the first few hours. ${ }^{11}$ While the second phase is related to the release of prostaglandins like substances in 2-3 hours. Second phase is sensitive to both the clinically useful steroidal and nonsteroidal anti-inflammatory agent. ${ }^{12}$ Prostaglandins are the main culprit responsible for acute inflammation. Theophyelline might be containing some anti-inflammatory agent which is responsible for the blockage of prostaglandins and inflammatory pathway.

In this model of inflammation, theophylline had very consistent anti-inflammatory activity and thus showed significant decrease in the paw edema of rat. Numerous studies have suggested that theophylline is having an anti-inflammatory property. For example, in vitro, theophylline mitigates the neutrophil respiratory burst and leukotriene metabolism. ${ }^{13,14}$ Theophylline also mitigates the respiratory burst and killing mediated by bronchoalveolar lavage-derived alveolar macrophages. ${ }^{15}$ Similarly, in an in vivo animal model, therapeutic serum concentrations of theophylline are associated with a diminished leukocyte influx into a bacterial-challenged lung and diminished bactericidal activity. ${ }^{16}$

The present results supports that theophyelline suppresses the carrageenan-induced paw edema, thereby acts as an anti-inflammatory agent. This may be due to inhibition of the mediators of inflammation such as histamine, serotonin and prostaglandin. Thus, confirming theophyelline as an NSAID-like property.

\section{CONCLUSION}

In summary, our results confirm that theophylline exhibit a marked anti-inflammatory property at all dose levels. But these findings need to be validated by further studies.

\section{ACKNOWLEDGEMENTS}

The authors would like to thank the Sri Siddhartha Medical College, Tumkur for their support.

\section{Funding: None \\ Conflict of interest: None declared}

Ethical approval: The study was approved by the Institutional Animal Ethics Committee

\section{REFERENCES}

1. Mahat MA, Patil BM. Evaluation of antiinflammatory activity of methanol extract of Phyllanthus amarus in experimental animal models. Indian J Pharma Sci 2007;69:33-6.

2. Sosa S, Balick MJ, Arvigo R, Esposito RG, Pizza C, Altinier G, Tubaro A. Screening of the topical anti-inflammatory activity of some Central American plants. J Ethnopharmacol 2002;81:211-5.

3. Amdekar S, Roy P, Singh V, Kumar A, Singh R, Sharma P. Anti-Inflammatory Activity of Lactobacillus on Carrageenan-Induced Paw Edema in Male Wistar Rats. Int J Inflam 2012;2012:752015.

4. Barnes PJ. Theophylline: new perspectives for an old drug. Am J Respir Crit Care Med 2003;167:813-8.

5. Milgrom H, Bender B. Current issues in the use of theophylline. Am Rev Respir Dis 1993;147(6 Pt 2):S33-9.

6. Sullivan P, Bekir S, Jaffar Z, Page C, Jeffery P, Costello J. Anti-inflammatory effects of low-dose oral theophylline in atopic asthma. Lancet 1994:343:1006-8.

7. Torphy TJ, Undem BJ. Phosphodiesterase inhibitors: new opportunities for the treatment of asthma. Thorax 1991:46:512-23.

8. Spatafora M, Chiappara G, Merendino AM, D'amico $\mathrm{D}$, Bellia V, Bonsignore G. Theophylline suppresses the release of tumour necrosis factor-a by blood 
monocytes and alveolar macrophages. Eur Respir J 1994;7:223-8.

9. Kulkarni SK. Handbook of Experimental Pharmacology. 3rd ed. Delhi: Vallabh Prakashan; 2007:128-31.

10. Wills AL. Release of histamine, kinin and prostaglandins during carrageenin induced inflammation of the rats. In Prostaglandins, Peptides and Amines. Montagazza P, Horton EW, Eds. Academic Press, London, UK; 1969:31-48.

11. Bhukya B, Anreddy RNR, William CM, Gottumukkala KM. Analgesic and anti-inflammatory activities of leaf extract of Kydia calycina Roxb. Bangladesh J Pharmacol 2009;4:101-4.

12. Brooks PM, Day RO. Non-steroidal antiinflammatory drugs difference and similarities. N Engl J Med 1991;324:1716-25.

13. Nielson CP, Crowley JJ, Cusack BJ, Vestal RE. Therapeutic concentrations of theophylline and enprofylline potentiate catecholamine effects and inhibit leukocyte activation. J Allergy Clin Immunol 1986;78:660 -7.

14. Nielson CP, Crowley JJ, Morgan ME, Vestal RE. Polymorphonuclear leukocyte inhibition by therapeutic concentrations of theophylline is mediated by cyclic-3',5'-adenosine monophosphate. Am Rev Respir Dis 1988;137:25-30.

15. O’Neill SJ, Sitar DS, Klass DJ, et al. The pulmonary disposition of theophylline and its influence on human alveolar macrophage bactericidal function. Am Rev Respir Dis 1986;134:1225-8.

16. Nelson S, Summer WR, Jakab GJ. Aminophyllineinduced suppression of pulmonary antibacterial defenses. Am Rev Respir Dis 1985;131:923-7.

doi:10.5455/2319-2003.ijbcp20130612

Cite this article as: Srinivasa K, Chandrasekhar BVS, Srinivasa J. Anti-inflammatory activity of theophylline on carrageenan-induced paw edema in male wistar rats. Int J Basic Clin Pharmacol 2013;2:298-301. 